\title{
LAWFUL SOLUTIONS FOR VIOLATION ON WOMEN IN SPORTS
}

\section{Zuzana Sakáčová}

\section{Department of Sport Educology and Sport Humanities, the Faculty of Physical Education and Sport, Comenius University, Bratislava}

\begin{abstract}
Summary: This contribution deals with the legal aspects and acts of violence against a group of women in sport. Discussions about violence in society and thus on violence in sport are often associated with people's thoughts about the moral state of society as a whole. Violence against women is one of the most widespread violations of human dignity. It represents a violation of human rights, namely the right to life, the right to safety, the right to dignity, the right to physical and mental integrity. It is desirable to raise awareness about the prevention of sexual violence at all levels. We have to focus on preventive precautions to support projects to fight violence and intolerance in sport, to develop codes of conduct that determine the relationship between athletes, relations between men and women, as well as relations between coaches and officials, relations between parents and coaches. The Slovak Republic is only at the beginning of the way of creating the relationship between law and sport. Therefore, it is necessary to increase the legal awareness of sport as a tool for regulation in sport activities.
\end{abstract}

Key words: violence, violence against women, violence against sportswomen, criminal offences, sexual harassment, abuse.

DOI 10.1515/afepuc-2015-0011

(C) Acta Facultatis Educationis Physicae Universitatis Comenianae 


\section{Introducion}

The aim of this work is to extend the knowledge-based sphere of legal aspects of protection in acts of violence on a group of women in sport. The presented study focuses on current issues of legal aspects of violence in the social group of women in the Slovak Republic, whose starting point is the analysis of the current Slovak legal system. It provides an analysis of the relevant legal documents and the Anti-Discrimination Act and the Criminal Code. It is pointing to the lack of legal instruments to protect women against violent behaviour in sport through sports legislation. In Slovakia, there is an absence of the appropriate structures to prevent sexual and gender-based harassment and abuse in sport. This work could contribute to optimization of the model of legal protection for women in the forthcoming law on sport in the Slovak Republic (2016), which would be more preventive and effectively treated to avoid major conflicts that result in violence against women in sport and can cause serious negative injuries to the physical and psychological health of sportswomen. In Slovakia, there are not any cases in judicial practice that would convince women athletes to effective protection of their rights, especially of their dignity.

The right not to be exposed to the violence or threat of violence is a fundamental and universal human right. Violence against women is one of the most spread violations of human dignity. It represents a violation of human rights, namely the right to life, the right to safety, the right to dignity, the right to physical and mental integrity. The terms "violence against women" and "gender-based violence" are used to describe a whole range of violent behaviour against women that have their origin in gender inequality and unequal position of women and men in society. Therefore, the European Union (EU) called on Member States to improve their national laws and policies to combat all forms of violence against women, particularly by developing comprehensive national action plans to combat violence against women, based on an analysis of the consequences of violence against women in terms of gender equality and liabilities. EU Member States is clear from international treaties with regard to the elimination of all forms of Discrimination against Women. It contains specific measures to prevent male violence, protect victims and prosecute perpetrators. EU calls for creating mechanisms to facilitate the availability of free legal aid for women (European Parliament resolution of 26 November 2009 on the elimination of violence against women). Similarly, the Fifth World Conference on Women and Sport (2012) recognizes the full right of women to participate freely in sports, encourages a greater participation of women sportswomen in sport and its development. It defines gender equality as an objective in sport for development initiatives 
and stresses that the World Conferences on Women and Sport led to major progress in the field of women's sports around the world.

\section{Theoretical analysis of the problem}

Violence has its theoretical - philosophical, sociological, psychological, educational, anthropological and legal aspects; it is a focus of criminology and sociology of crime. This issue in a broad spectrum give an answer to what can be considered as violence, how it manifests itself, what are the most common causes of its existence, how can he defend (Spurný 1996, s. 7). Violence can be generally defined as the intentional use of physical force or power, but probably either threatened or actual, against a person or against a group or community that either results in or has a high likelihood of resulting in bodily injury, death, psychological damage and so on. Inherent category of violence and the threat of pain is pain. The violence, which causes pain, is a source of powerlessness of the victim and at the same time an expression of survival can perpetrator over his victim.

Slovak Republic (SR) adheres to all relevant international documents regulating the human rights (UN Declaration on the Elimination of All Forms of Discrimination against Women (1993); the UN Declaration on stopping violence against women (1994); the Convention on the Elimination of All Forms of Discrimination against Women 1979). In Article 2 of the UN Declaration lists a number of forms of violence (some of which are tied to the cultural context - traditional practices and SR practically do not occur).

Among them are:

a) Physical, sexual and psychological violence occurring in the family, including battering, sexual abuse of female children in the household, dowry - related violence, marital rape, female genital mutilation and other traditional practices harmful to women, non-spousal violence and violence related to exploitation;

b) Physical, sexual and psychological violence occurring within the general community, including rape, sexual abuse, sexual harassment and intimidation at work, in educational institutions and elsewhere, trafficking in women and forced prostitution;

c) Physical, sexual and psychological violence perpetrated by the State, or by passive state into account, regardless of where this violence occurs.

UN Declaration on the Elimination of Violence against Women (1993, par. 1.2), the term violence against women "as any act of violence based on gender inequality, which aims to result in, physical, sexual or psychological harm or suffering to women, including threats 
of such acts, coercion or any deprivation of liberty, whether occurring in public or private life”. Sexual violence "is any non-consensual sexual activity including: sexual taunts and jokes, staring and leering, unwelcome comments, flashing (exposure), offensive phone calls, unwanted sexual propositions, forced viewing of/or participation in pornography, unwanted touching, coerced sex, rape, incest, being made to perform sexual acts the woman finds painful or humiliating, forced pregnancies, trafficking and exploitation in the sex industry" (Final Report of Activities of the Group of Specialists for Combating Violence Against Women, EG-S-VL (97) 1 Council of Europe 1997, p. 14).

The International Olympic Committee (2007, p. 3) issued a Consensus Statement which reported that:"Sexual harassment and abuse in sport stem from power relations and abuses of power. Sexual harassment refers to behaviour towards an individual or group that involves sexualised verbal, non-verbal or physical behaviour, whether intended or unintended, legal or illegal, that is based upon an abuse of power and trust and that is considered by the victim or a bystander to be unwanted or coerced. Sexual abuse involves any sexual activity where consent is not or cannot be given. In sport, it often involves manipulation and entrapment of the athlete. Sexual harassment and abuse occur within an organizational culture that facilitates such opportunities. Indeed, they are symptoms of failed leadership in sport". In November 2012 took place in Berlin Conference "Safer, better, stronger! Prevention of sexual harassment and abuse in sports". The main objective is to raise awareness on the prevention of sexual violence at all levels of European sporting environment.

Based on the general definition of violence on an international level, it can for violence against women is considered any act against a woman if the act restricting the legal rights and freedoms and causes her physical or psychological suffering and moral damages. The issue of violence against women can be seen as a global problem, an increasing interest in the Slovak Republic (Cviková a Juráňová 2001; Bodnárová a Filadelfiová 2002; Filadelfiová 2005; Bodnárová, Filadelfiová a Holubová 2008; Mátel 2009). According to a representative survey the incidence and women's experiences with violence against women (by the intimate partner - current or past) carried out in 2008 in Slovakia, violence against women is a serious social problem. Hit a large group of women affected areas from childhood to adulthood, intimate relationships including. Every fifth adult woman who currently has a partner experienced by him violent behaviour-precisely $21,2 \%$ of adult women the age group $18-64$ years. The incidence of violence against women from former partners is even higher: from 
adult women who had former partner, experienced by him violent behaviour $27.9 \%$, of which $12.2 \%$ pronounced violence (National Action Plan for the Prevention and Elimination of Violence against Women for the years 2014 to 2019). As stated in the draft National Action Plan on preventing and eliminating violence against women for the years $2014-2019$ in Slovakia lacks a systemic approach and ensuring coordinated both help women experiencing violence (secondary and tertiary prevention), as well as systematic primary prevention, prevention of violence, which It is weakened ability to provide real assistance to women experiencing violence. The document proposes to strengthen the legal and institutional framework to protect women against violence and enabling them effectively help them obtain such rights.

In terms of us examined issue and committing various forms of violence, harassment, sexual harassment and sexual abuse against women in sport, we must state that this serious issue in Slovakia insufficient attention not only in theory, but especially in the research area. We have a limited amount of empirical evidence on violence, harassment and sexual harassment in sport. In the Slovak Republic, there is a lack of appropriate structures for the prevention of sexual and gender-based harassment and abuse in sport. It is related to the fact that many women, thus sportswomen, frequently do not clearly assess whether it was really about harassment, whether such conduct was illegal to whom they can turn, who can advise them how to be able to demonstrate and so on. As reported Ondrejkovič (2008 p. 398), "violence is the key to research and knowledge of the various forms. Until we are not going to do, it remains for us only an abstraction violence resulting correlations social, economy and culture that we consider the conditions in which it is formed". It would seem that the problem is not with us. However, the opposite may be true.

On the other hand, research in the various countries of the world such as Canada, USA, Norway, Germany, Netherlands, United Kingdom, Denmark, Czech Republic and others point to the systematic investigation of this serious problem (Toftegaard Nielsen 2001; Alexander, Stafford and Lewis 2011; Fasting and Knorre 2005; Jolly and Décamps 2006; Décamps, Dominguez, Jolly and Afflelou 2011; Chroni and Fasting 2009; Palmer 2011), it also proves the research of the Czech Republic by the authors Fasting and Knorre (2005) entitled "Women in Sport in the Czech Republic - Experience sportswomen" whose objective was to assess the current situation and role of women in sport and sports organizations in the Czech Republic. In section 4, "Security and experienced unwanted sexual attention" research shows that some form of sexual harassment experienced by up to $72 \%$ of research 
participants. This figure can be considered very high. The situations where the degrading remarks about them, as well as the way the trainer treats them are part of them. In relation to physical harassment the question: "Have you ever been hit to the by your coach or a member of the team?" answered around 53 sportswomen, including (9\%) answered this question "yes". That someone hits them, it is becoming generally more senior sportswomen (11\%) compared to the performance $(9 \%)$ and recreational $(6 \%)$. The research questions that were asked included sexual harassment. 1. Unwanted physical contact ( kissing against your will, hugging, pinching and etc.) 2. Repeated inappropriate comments with sexual overtones, remarks and jokes about the clothes, private life etc. 3. Making jokes on your athletic performance to you as sportswomen for your gender. Research has shown that sexual harassment can have a serious impact on sportswomen, in the form of insomnia, depression, impaired performance at work and in sport, reduced ability to concentrate, sick leave at work and in sports, persistent feelings of shame and guilt, decreased athletic performance, the negative impact on family life and parenthood, or even complete abandonment of the sports and social activities. As reported by the study, the percentage is very high, so it will be necessary to take measures for prevention of such forms of violence in sport (Fasting - Knorre 2005). To the above can be assigned a more sleep, failure to trust the other, destructive behaviour, difficulties in establishing new relationships, increased use of alcohol or a drug, etc.

Physical, social and emotional relationships during sports and recreational activities are very important for the development of social cohesion, not only for children and adolescents but also between sportsmen and sportswomen among athletes/sportsmen and trainer / coach the trainer and coaches of all ages. These moral relationships are based on trust between the individuals and it is necessary to say that they have an important role in the training process, during matches or sporting events. They are part of the success of an individual or a whole team. This is a very well known, tolerated so-called "Friendly raillery" in which the admiration knowingly certain limits. Therefore, it is not possible unequivocally do the table about what is $100 \%$ sexual harassment, since the same behaviour in different contexts can have very different parameters.

Sexual harassment is something unwanted by the other party. Sexual harassment is considered as discrimination, which is subject by power. It represents the control of the other party, is uncomfortable, creates an intimidating or degrading environment, and undermines personal integrity, dignity of another person. This may take the form of verbal, represented for 
example by using different jokes, sexually oriented comments, allusions to the appearance of the legs, abdomen, breasts, sex life, or used different gestures, shouting, bullying, ridiculing the weaker performance, use pranks based on sex, sexually intimidating notes, meeting invitations, offensive phone calls, text messages, e-mails or letters with sexual content, negotiated or unapproved naming like the cat, chick, chicken, rabbit, awkward questions to privacy, for example sexual orientation, putting up pictures of naked women, and so on. Very discussed topic in sport is also, for example, vulgar insults from the side of coach. Furthermore, it can be a form of nonverbal such ambiguous gestures, gestures, different manifestations such as sounds like munching, whistling, looking "undressing view" and so on. Other annoying may have insights physical presence to a certain distance. Finally, it can be physical manifestations as "inadvertent touches" pushing the victim, abrading, grope certain parts of the body, coercing sexual contact, sexual extortion, physical assault, rape, forced sex. Sexual harassment may not be the only from side of men but also by women.

The Slovak legislation by Act no. 365/2004 Coll. on equal treatment in certain areas and protection against discrimination and amending certain laws (Antidiscrimination Act) is defined by the notion of harassment. It is also a behaviour, which may result in creating an intimidating, hostile, degrading, humiliating, or offensive attitude (environment) and whose intention or effect of which is, or may be, interference with freedom, or human dignity. The definition of sexual harassment in the Act. 85/2008 Coll., Which the Amending antidiscrimination law, with effective from $1^{\text {st } A p r i l ~} 2008$ ( $\S 2 \mathrm{a}$, paragraph. 4 and 5 of the Antidiscrimination Act) states, that "sexual harassment is verbal, non-verbal or physical conduct of a sexual nature, purpose or effect, or may be a violation of the dignity of the person and which creates an intimidating, degrading, humiliating, hostile or offensive environment". The basic characteristic of sexual harassment is that it is for that person unwelcome. Sexual harassment is from friendly behaviour, which is welcome, mutual, distinguished by it is adverse in nature, and it may interfere with a person's dignity and creating an intimidating, hostile, degrading, humiliating, hostile or offensive environment. Sexual harassment therefore constitutes an infringement of the principle of equal treatment. Harassment is the asymmetry in the situation where one participating party is uncomfortable and generally cannot afford to resist. In such cases, it is possible to go to court and civil action can be achieved by apology or compensation for non-pecuniary damage. The amount of nonpecuniary damages in cash is determined by the court taking into account the severity of nonpecuniary damage and all the circumstances in which it was incurred. The application 
practice, the individual attacks rather considered as a misdemeanour (such as a lower form of socially dangerous illegal action), therefore no crime. It applies more often Act. 372/ 1999 Coll. Act offenses. It is therefore possible to initiate an infringement procedure by submitting a notice for the offense against civic propriety. A person who defames another by offending or ridiculing, or who deliberately undermines civil coexistence threatening bodily harm, minor bodily harm, or other abusive behaviour commits such an offense. Pursuant to the provisions of the Act to the procedures, the degree of danger to society is less than the offense (misdemeanour sexual harassment does not exist).

Sexual harassment in the Slovak legal systems without the use of sexual violence is not a criminal offense. The definition of violence is defined in the Criminal Code in $\S 122$ criminal offenses and committing his ways. The basic facts of the case in point. (7): "The criminal offence is considered as having been committed with the use of violence if the offender uses physical violence against physical integrity of another person, or if it is committed against a person whom the offender induced into a state of helplessness by deception, or if the offender used violence against a thing of another" and paragraph (8): "The criminal offence is considered as having been committed with the use of coercion if the offender commits it with the use of psychological violence against another person". In the event that the conduct of the coach came into the merits of the batter crime, both in particular cases it could be under the Act No 300/2005 Coll. Criminal Code as amended transcripts as follows: Offences against Human Dignity § 199 Rape (1) Any person who, by using violence or the threat of imminent violence, forces a woman to have sexual intercourse with him, or takes advantage of a woman's helplessness for such act, shall be liable to a term of imprisonment of five to ten years (5 - 10 years); $§ 200$ Sexual Violence (1) Any person who, by using violence or the threat of imminent violence, forces another to engage in oral sex, anal sex, or any other sexual acts, or takes advantage of another's helplessness for such act, shall be liable to a term of imprisonment of five to ten years (5 - 10 years). § 201 Sexual Abuse (1) Any person who has sexual intercourse with a person under fifteen years of age, or who subjects such person to other sexual abuse, shall be liable to a term of imprisonment of three to ten years (3 - 10 years). Objects are protection of child development and unreachability in the sexual sphere. When applying this, it is unimportant, if the person younger than 15 years of age agrees to the sexual intercourse with the other person, since the penal code prohibits any form of sexual intercourse for individuals younger than 15 years. This constitution provides for a person younger than 15 years protection before heterosexual 
and homosexual acts; § 202 (1) Any person who makes a person under eighteen years of age to have an extramarital intercourse, or who otherwise subjects a person to sexual abuse, a) if such person has been placed under his care or custody, or has been dependent on him, or b) in exchange for money, shall be liable to a term of imprisonment of one to five years (1 - 5 years); § 208 Battering a Close Person and a Person Entrusted into one’s Care: shall be liable to a term of imprisonment of three to eight years (3 - 8 years). The Act further specifies various forms of torture: a) repeated beating, kicking, hitting, inflicting various types of wounds and burn wounds, humiliating, disregarding, continuous stalking, threatening, evoking fear or stress, by forced isolation, emotional extortion or by other improper conduct endangering his physical or psychical health, or putting his safety at risk, b) repeated and unjustified denial of food, rest or sleep, or denial of necessary personal care, basic clothing, elementary hygiene, health care, housing, upbringing or education, c) forcing to beggary or to a repeated performance of activities causing excessive physical strain or psychical stress for the person subject to ill-treatment considering his age or health condition, or damaging his health, d) repeated exposure to the effects of substances that are detrimental to his health, or, e) unjustified restriction on his right of access to the assets that he is entitled to use and enjoy; $\S 360$ Serious Threats (1) Any person who threatens another with killing, inflicting grievous bodily harm or other aggravated harm to an extent which may give rise to justifiable fears shall be liable to a term of imprisonment of up to one year.

In the sports world, however, we are known cases of violence (harassment) at sportswoman perpetrated and committed trainers (N. Comaneci - Romania, O. Korbut USSR and others). American figure skater Jessica Roos appealed to his coach for sexual harassment. From the Czech sports environment it is known case of gymnastic coach M. Simunek, who was the judgment of the Supreme Court of the Czech Republic (11 Tdo File No. 759/2006) found guilty of the offense of sexual abuse and sentenced to imprisonment for five years (decision of the Supreme Court Czech Republic).

Violence against women in sport is of interest to the greatest extent, especially by the media. Women (children, adolescents) and sportswomen are becoming more widely targets of violence, harassment, various "deviant elements" - "fans", "admirers", but also violence from their family members. This is evidenced by sportswomen statements which, during sporting career under the strong influence of their fathers (mothers as well), not only persistently try to take part in the training process, but also an interfere with their private life. Parent's don't just stand on the sidelines, but in many sports they are part of the implementation team, or act as 
coaches. Among the most famous cases that have been well-publicized cases, include tennis players Mary Pierce and her father Jim Pierce. According to the testimonies of his daughter, she's was beaten and humiliated repeatedly during her trainings. WTA (Women's Tennis Association) punished the father by banning him entries to the tournaments for a period of five years. WTA also banned entry to tournaments for a French tennis player Aravane's father Rezai. Her father, who trained her well, was known for violent behaviour. In addition, the father of Russian tennis players Jevgenie Linecki in 2005 was penalized by a two-year ban on entry to WTA action. Her coach Joe Giuliano received a lifetime ban entry. Linz tolerated and promoted the cruel behaviour Giuliano to his daughter. Her coach at the tournament in San Diego went too far - she had to be transferred to the hospital. In 2007, the worldswimming champion in Melbourne, a coach, Mikhail Zubkov bates his daughter Catherine. The incident was recorded on camera and FINA (The Fédération Internationale de Natation The International Swimming Federation) banned Zubkov father to train six years. Other sportswomen speak about negative experiences with the practice of the various forms of violence that were committed to them and to the part of their former coaches, managers or members of the implementation teams. The motivation may be sexual abuse, as well as hatred, anger. Offenders may also be homosexuals, heterosexuals or bisexuals, and they may be directed to certain age groups such as adolescents (hebephilia) or children (pedophilia). This may not always be just sexual abuse, harassment, but it may be a different form of psychological coercion or even the various forms of blackmail „non-compliance“ personal space and so on.

Some already committed acts that were courtly qualified as crimes of bodily harm or grievous bodily harm. The public in the last decade is known as horrific acts of harassment athletes - women, deranged fan (it was a worshiper Steffi Graf) and his attack on the then world number one Monica Seles. In Hamburg, April 30th, 1993, 38 - year old Günter Parche stabbed her viciously with a kitchen knife several times in the back. Monica Seles was lucky and survived the attack, but it took several months of treatment. However, consequences that are more serious meant psychological problems. After returning to the world court, she could never restore her former performance that she used to deliver before the injury. Günter Parche was by court later described as mentally disturbed; he got only a two years conditional and compulsory psychiatric treatment. However, this attack banned us from having one of the most accomplished tennis players in history. In 2008, he completed a career. Another known case, in which, like the previous sequel was in court, is a Swiss tennis player Martina Hingis, 
which, like other women sportswomen has been targeted by a 46 Croat (with an Australian passport) that bothered her, sending her love affairs faxes, letters and flowers, even visited her, after she arrived in Switzerland and he attended the WTA tournament in which sportswoman started. In court he wanted to convince the judge that he is in love with her, but this "did not affect the jury" and he finally got sentenced to prison for two years. Before retiring in 2007, she attended Wimbledon, which she quit in the third round. Shockingly, the results from the laboratory found A and B samples of her urine to be positive when tested for cocaine. Hingis, however, rejected the allegation and wanted to prove her innocence. In 2008, she prematurely ended her career. Similar is the case with Serena Wiliams at WTA tournament in Rome (2002), where a German tennis fan Albrecht Stromeyer tried to get into the space reserved for the players. Members of the security services arrested him and he had to face accusations for harassment of American players.

Media reported cases of harassment of women, sportswomen from the media themselves, in the form of paparazzi. An example is the violence of French journalists from the television channel M6, towards Anna Kournikova, who during the WTA tennis tournament (Swiscoom Challenge in Zurich) called for an interview and chased her into the hotel. The Sportswoman had to ask the Tennis Association for help, consequently the reporters' accreditation was withdrawn and they were expelled from the hotel. This was the first time that tennis players had to use such funds.

In these cases, media have negative dimensions. On the other hand, the media can work positively, as they play an important role in informing the public about violence in sport. Published reports of violence against women in sport are very emotional. Media warned that the numbers of detected cases of violence in sport would be greater if the victims of violence women, girls, but also their parents, coaches and members of the implementation teams worked with journalists to provide the facts to the media and especially if they were transmitting information. This would contribute to the protection of athletes. The media should act as "advocates of sportsmen", they should assist in clarifying violence in sport and they would thrive on increasing legal awareness of all participants in sports events.

\section{Conclusion}

Behind every athlete, there is a human story. Sport imitates real-life situations, which also bring victories and losses, rises and falls, which need to be overcome and then keep walking. Athlete serves the viewer as a model, which could be replicated, in everyday life. It 
is a hero who overcomes obstacles honestly fighting for victory respecting the rules. In this case, sport serves as formation of positive personality traits, socially acceptable values and behaviour patterns. It is very important that Slovakia became aware of the problem of violence against women but also against children, violence against women in sport, as a problem of the whole society. It is essential to continuously improve and build a knowledge base on cases of violence against women in the Slovak Republic. It is necessary to support projects to combat violence and intolerance in sport.

We all have to cross the border that separates the private and public sphere, beyond what makes it so serious problem invisible. Because hardly any woman can stop the machinery of physical and psychological attacks. Men's violence against women will stop only when the society stops tolerate this violence and trivialize it..

\section{References}

1. ALEXANDER, K., A. STAFFORD a R. LEWIS, 2011. The Experiences of Children Participating in Organised Sport in the UK. Edinburgh: NSPCC.

2. BODNÁROVÁ, B., J. FILADELFIOVÁ a B. HOLUBOVÁ, 2008. Reprezentatívny výskum výskytu a skúseností žien $s$ násilím páchaným na ženách (VAW) na Slovensku. Bratislava: IVPR.

3. BODNÁROVÁ, B. a J. FILADELFIOVÁ, 2002. Domáce násilie na Slovensku. Bratislava: Stredisko pre štúdium práce a rodiny. ISBN 80-89048-06-4.

4. CVIKOVÁ, J. a J. JURÁŇOVÁ, 2001. Piata žena. Aspekty násilia páchaného na ženách. Bratislava: Aspekt. ISBN 80-85549-28-X.

5. DÉCAMPS, G., N. DOMINGUEZ, A. JOLLY and S. AFFLELOU, 2011. Les violences sexuelles et leurs répercussions psychologiques chez les sportifs. In: DÉCAMPS, G. (Ed.) Psychologie du sport et de la santé. Chapter: 19. Bruxelles: De Boeck, pp.349-362.

6. Doporučení Evropské komisii. Bezpečněji, lépe, silněji! Prevence sexuálního obtěžování a zneuživání ve sportu. [online]. 2013 [cit.2013-10-02]. Dostupné z www.olympic.cz.

7. FASTING, K. a N. KNORRE, 2005. Ženy ve sportu v České republice. Praha: Norská sportovní univerzita a Český olympijský výbor Oslo a Praha. ISBN 80-239-5723-6.

8. FASTING, K., 2013. Preventing sexual harassment in sport - a need for transforming coaching education? [online]. 2013 [2015-03-02]. Dostupné z: http://www.ewsonline.org/files/doc/Conference-Paris/Fasting.pdf. 
9. FASTING, K., C. BRACKENRIDGE and J. SUNDGOT-BORGEN, 2000. Females, Elite Sports and Sexual Harassment. The Norwegian Women Project. Oslo, Norwegian Olympic Committee.

10. FASTING, K., C.H. BRACKENRIDGE and J. SUNDGOT-BORGEN, 2004. Prevalence of sexual harassment among Norwegian female elite athletes in relation to sport type. International Review for the Sociology of Sport, 39(4), 373 - 386.

11. FILADELFIOVÁ, J., 2005. Stav násilia páchaného na ženách v SR. In: BÚTOROVÁ, Z., FILADELFIOVÁ, J., et.al. Násilie páchané na ženách ako problém verejnej politiky, Bratislava: IVO.

12. Final Report of Activities of the Group of Specialists for Combating Violence Against Women, EG-S-VL (97) 1, Rada Európy, 1997.

13. Holubová, B., 2007. Sexuálne a šikanózne obtažovanie žien na pracovisku. VÚ 22192007. Bratislava: Inštitút pre výskum práce a rodiny [online]. 2007 [2015-04-02]. Dostupné na: http://www.sspr.gov.sk/IVPR/images/IVPR/vyskum/2007/Holubova.pdf

14. CHRONI, S. and K. FASTING, 2009. Prevalence of male sexual harassment among female sport participants in Greece. Inquiries in Physical Education \& Sport, 7(3), 254262.

15. CHRONI, S. et al., 2012. Sexual and gender harassment and sexual abuse: Initiatives for prevention in sport. Frankfurt: Deutsche Sportjugend im Deutschen Olympischen Sportbunde.V.

16. International Olympic Committee. 2007. Consensus statement on "Sexual harassment \& abuse in sport”. Lausanne, 8 February 2007 [online]. 2007 [cit. 2015-03-05]. Dostupné z: http://www.olympic.org/content/news/media-resources/manual-news/19992009/2007/02/08/ioc-adopts-consensus-statement-on-sexual-harassment-and-abuse-insport/

17. JOLLY, A. a G. DÉCAMPS, 2006. Les agressions sexuelles en milieu sportif: une enquête exploratoire. In: Science et Motricite, 57(1), 105 - 121. ISSN 1378-1863.

18. MÁTEL, A., 2009. Naše možnosti pomoci ženám - obetiam domáceho násilia. Skalica: Občianske združenie ALIJA. ISBN 978-80-970083-1-4.

19. National Action Plan for the Prevention and Elimination of Violence against Women for the years 2014 to 2019 (Národný akčný plán na prevenciu a elimináciu násilia na ženách na roky 2014 - 2019) 2013 [online]. 2014 Dostupné z: 
1t.justice.gov.sk/Attachment/Vlastnymat_doc.pdf?instEID=1\&attEID=59764\&docEID=3 $31654 \&$ matEID $=6656 \&$ langEID $=1 \&$ tStamp $=20131007181553383($

20. HEJDIŠ, M. et.al., 2009. Sociálna a ekonomická núdza - bezpečnost' jedinca a spoločnosti. Bratislava: VŠZaSP Sv. Alžbety v Bratislave. ISBN 978-80-89271-63-4.

21. ONDREJKOVIČ, P., 2008. Násilie-spoločensky nežiaduci jav. In: Sociológia 40(5), 391-416. ISSN 0049-1225.

22. PALMER, C., 2011. Violence against women and sport [online]. 2011[2015-02-02]. Dostupné z:http://www.endviolenceagainstwomen.org.uk/data/files/resources/22/EVAWViolence-Against-women-and-Sport-Dr-C-Palmer-July-2011.pdf

23. Rozsudek Nejvyššího soudu ČR z dňa 26.1.2007, sp. zn. 11 Tdo 759/2006.

24. SPURNÝ, J., 1996. Psychologie násilí : o psychologické podstatě násilí, jeho projevech a způsobech psychologické obrany proti němu. Praha: Eurounion. ISBN 80-85858-30-4.

25. 5th World Conference on Women and Sport [online]. 2012 [2015-01-02]. Dostupné z: http://www.olympic.org/news/5th-world-conference-on-women-and-sport-calls-formore-women-in-leadership-roles/154587

26. TOFTEGAARD-NIELSEN, J., 2001. The forbidden zone: Intimacy, sexual relations and misconduct in the relationship between coaches and athletes. International Review for the Sociology of Sport, 36(2), 165-182.

27. European Parliament resolution of 26 November 2009 on the elimination of violence against women (Uznesenie Európskeho parlamentu z 26. novembra 2009 o odstránení násilia páchaného na ženách (2010/C 285 E/07) [online]. 2009 [2015-04-05]. Dostupné z: http://www.europarl.europa.eu/sides/getDoc.do?pubRef=-//EP//TEXT+TA+P7-TA-2009$0098+0+\mathrm{DOC}+\mathrm{XML}+\mathrm{V} 0 / / \mathrm{SK})$

28. Act. 372/1999 Coll. Act offenses (Zákon č. 372/1999 Zb. o priestupkoch).

29. Act No 300/2005, The Criminal Code, as amended ( Zákon č. 300/2005 Z.z. Trestný zákon v znení neskorších predpisov).

30. Act No 301/2005 Code of criminal procedure, as amended (Zákon č. 301/2005 Z.z. Trestný poriadok v znení neskorších predpisov).

31. Act No 365/2004 on equal treatment in particular areas and about protection against discrimination and on amendments to certain laws (Anti - discrimination Law) (Zákon č. $365 / 2004$ Z. z. o rovnakom zaobchádzaní v niektorých oblastiach a o ochrane pred diskrimináciou a o zmene a doplnení niektorých zákonov (antidiskriminačný zákon). 
32. Zákon č. 85/2008 Z.z. ktorým sa mení a dopín̆a zákon č. 365/2004 Z. z. o rovnakom zaobchádzaní v niektorých oblastiach a o ochrane pred diskrimináciou a o zmene a doplnení niektorých zákonov (antidiskriminačný zákon) v znení neskorších predpisov a o zmene a doplnení zákona Národnej rady Slovenskej republiky č. 308/1993 Z. z. o zriadení Slovenského národného strediska pre l'udské práva $\mathrm{v}$ znení neskorších predpisov (the Act. 85/2008 Coll).

33. Act No 311/2001 Coll., The Labour Code, as amended (Zákon č. 311/2001. Z.z Zákonník práce $\mathrm{v}$ znení neskorších predpisov).

34. Act No. 300/2008 Coll. On the organisation and support of sport as later amended (Zákon č. 300/2008 Z. z. o organizácii a podpore športu a o zmene a doplnení niektorých zákonov).

35. UN Declaration on stopping violence against women (1994) ( Deklarácia OSN o zastavení násilia proti ženám) (1994).

36. UN Declaration on the Elimination of All Forms of Discrimination against Women (1993) (Deklarácia OSN o odstránení násilia páchaného na ženách) (1993).

37. Convention on the Elimination of All Forms of Discrimination against Women 1979 (Dohovor o odstránení všetkých foriem diskriminácie žien) (1979) . 